\title{
Politics in the Classroom: How the Exposure of Teachers' Political Views Impacts Their Students
}

\author{
Abigail Camp ${ }^{1}$ \\ ${ }^{1}$ Wando High School, Mount Pleasant, SC, USA
}

\begin{abstract}
$\underline{\text { ABSTRACT }}$
This paper examines the presence of teacher political publicity during instruction and its impact on students, looking specifically in the U.S. History classroom, where historical controversies can put teachers in positions where they express their political views during lessons. This is significant because American students are learning about the history of their nation through the personal perspective of their teacher. Much information has been collected on the subject of teacher neutrality within the classroom, but insufficient research exists on how this impacts students. My paper questioned how the exposure of a U.S. History teacher's political views during instruction contributed to the development of their students' views at the high school and college level. Using a mixed method approach, I collected quantitative and qualitative data through questionnaire surveys and found that teacher political publicity develops students' own political views at the high school and college level -but more so at college level- by strengthening the existing views of students and changing their perception of the course material. This discovery supports the existing idea that college professors have more political freedom and opens the door for research on whether this political exposure is beneficial or detrimental to students.
\end{abstract}

\section{Introduction and Literature Review}

The history of the United States of America is rich in controversial topics, questionable decisions, and delicate subjects. Any American student who walks into their United States History class should be prepared to listen with an open mind and expect to walk out with a new and improved grasp on the development and background of their country. Within the course material, multiple perspectives and approaches on issues arise within economics, religion, education, culture, domesticity, industry, and, encompassing all, politics. U.S. History teachers and professors have the utmost power when it comes to determining the way in which ideals on politics are presented to their students. Some teachers see the need to expose their students to as many controversial political topics and opinions as possible throughout the course, pulling from extraneous sources that add to the required subjects covered by the curriculum. Other teachers focus strictly on the curriculum and information provided to them and only go in depth on political topics that they believe are necessary. The reasons behind the differing methods come from a wide number of factors, including the amount of time allotted to teach the course or the assigned difficulty of the class. However, one of the most overlooked reasons is the fact that teachers themselves have different political opinions that they have developed throughout their lives. These opinions have the power to alter the way a teacher desires to teach certain civic topics within the course. Furthermore, due to the controversial nature of the history of the United States, teachers under this course can find themselves in a position where they express their own political views during instruction, knowingly or unknowingly. With this, students are taught not only the same course by teachers with differing political perspectives, but also by teachers with differing levels of exposure of their views to their students. This has brought up much controversy over the level to which teachers should implement their political views within their classrooms and whether or not their implementation is legal. With this, the question over whether or not a student's learning experience is evidently impacted by their exposure to their teacher's political opinions arises and can be explored on a narrower 
and deeper level. Looking within a relatively democratic county, how does the exposure of a United States History teacher's political views during classroom instruction contribute to the development of the political views of their students at the high school versus the college level?

\section{Definitions}

This research concentrates on the two democratic counties from the same southeastern state. A democratic county refers to a division of a state that tends to vote in favor of the democratic party (government by the people and rule of the majority). Both counties have a history of voting democratic, as most recently evidenced by the 2016 presidential election in which Hillary Clinton, the democratic candidate, was awarded 13,856 more votes than her republican counterpart, Donald Trump, in one of the counties as well as 55,531 more votes in the other county. What makes the political atmosphere of the two counties a unique area of study is the fact that the state they belong to is, as a whole, majority republican; the state gave Trump 60.6 percent of their votes in the same 2016 presidential election (South Carolina, 2017). The fact that these counties stick to their political side despite the contradictions of their state as a whole suggests that political views of citizens in the county might be more prominent and present, making the research more feasible.

To define the term political view, it refers to the ideology and body of doctrine that guides an individual, social movement, institution, or group in the political sense. The United States currently functions under a majority two-party system: Democrat and Republican. Democrats tend to favor the more liberal side of politics, speaking out in favor of social issues such as abortion, gun control, and health care as well as increased government spending within the economy and the raising of taxes for the wealthy. Republicans, on the other hand, tend to favor the more conservative side, and are against abortion, restrictive gun laws, and increased government intervention (Ideologies of Political Parties). However, these are just the stereotypical views, and there are outliers within each party.

\section{Levels of Exposure of Political Views in the Classroom}

There has been a degree of research conducted to examine the levels of political exposure in the classroom. The studies have found that there are stark differences and a number of reasons why some teachers implement their political views while others do not.

Typically, the teachers who restrain from exposing their own views tend to have three distinct qualities: they teach at the secondary education level, they desire to conceal their identity, and they fear backlash from their community in the case that they do choose to share their views. Joseph Wegwert, an assistant professor in the Department of Teaching and Learning at Northern Arizona University, states that at the high school level, teachers are "trained in an ideology of professionalism that eschews the complexities of context in favor of self-regulating neutrality" (Wegwert, 2014). This idea of teacher neutrality was a legal expectation that was merely referenced to within the U.S. Department of Education's teacher regulations. However, the lack of specificity on topic within the regulations paired with the freedoms and rights presented in the First Amendment have confused the public on whether or not it is just for teachers to share their political views in the classroom. This has led to a number of court cases, firings, and legal debates, mainly at the state level, that have ultimately tightened the grip on the expectation of teacher neutrality in and out of the classroom at the secondary education level. This limitation has instilled a certain fear within public high school teachers that encourages them to keep their identities sealed. This fear has also developed due to the increase of public backlash that teachers face from their communities. Wegert states, "both novice and veteran teachers face repeated and generalized assaults from the media, with school crisis and failure headlining" (Wegert, 2014). As the use of media and technology grows, so does the fear of rejection and resentment by society, especially when it comes to the teaching within public high schools.

On the other hand, teachers who do incline to share their own political views during instruction tend to have these three qualities: they teach at the college level, they desire to create an educated civic society, and they have the 
ability to personalize their course curriculum. College professors do not typically fear exposing their political identity due to the use of tenures. Because the professors' jobs are secure and relatively permanent, they do not have to fear being laid off for not abiding to certain regulations regarding their neutrality in the classroom. Furthermore, college professors tend to support the idea of creating an educated civic society that will be ready to face the politics of the real world. Wayne Joumell, a history professor at the University of North Carolina at Greensboro, summarizes this belief. "The obvious concern behind this lack of political knowledge is that poorly informed students ultimately develop into politically illiterate citizens. Throughout the political science literature are studies suggesting that Americans, as a whole, are becoming less knowledgeable about politics and government, less interested in how government works, and more distrusting of politicians and other public officials" (Joumell, 2014). This belief is commonly shared among college professors who see the need for their students to be prepared once they graduate and become responsible for their own political sphere. These professors implement both their own views as well as extraneous views in a multitude of ways. Laura Talmate, a U.S. History professor at California State University, uses music, advertising, political propaganda, and poetry examples to accentuate lecture and discussion points while Scott Waalkes, a professor of International Politics at Malone University, relies on using film clips as cases, which aids students' critical thinking and allowed the incorporation of comparative politics (Talamante, 2008) and (Waalkes, 2003). These professors utilizate outside sources for political exposure that reflects and asserts their own personal views into the material that is taught directly to their students.

\section{Overview}

Despite this abundance of information on the development and background of teacher neutrality versus personal political exposure within the classroom, there has been insufficient research gathered to see how this impacts students. Assuming that students at both the college and high school level have at least some degree of political views and have perceived a U.S. History course in their own way, I aim to measure the degree to which they have been affected by any type of exposure they have had to the personal political views of their teacher. Typically, society refers to family, race, gender, religion, and location as being the factors that develop one's own personal political identity. However, I aim to explore a possible connection between one's political identity and the way in which they were exposed to their teacher's political views while learning about the history of their nation.

\section{Methods}

I chose to conduct my research through a mixed method study, which gains a perspective on a topic through the collection and analysis of both qualitative and quantitative data. This provides the researcher with both descriptive and statistical evidence that allows for a greater understanding of the topic being studied. A mixed method fit specifically into my research because my design needed both quantitative and qualitative data in order to complete a thorough study on the level to which a student's political views are developed and impacted by their exposure to their teacher's political views during classroom instruction. Quantitative data specifically allowed me to gather statistics and percentages that helped evaluate the level to which students are affected by exposure to their teachers' political views. Qualitative data was used to determine these views as well as gain information through a questionnaire that got a better grasp on personal experiences and beliefs of the students and teachers in relation to the research topic.

My subjects of study were U.S. History teachers from a suburban, southeastern coastal high school and a group of their students, as well as a college professor of History from an urban college in a city and a group of her/his students from his U.S. History class on the American Revolution. These subjects are all located in relatively democratic counties within the same relatively republican state. I chose to study students of two different age groups (high school and college) in order to grasp a larger sample of the student population of young adults whose political views may or may not already be determined and fully developed as well as to see if there is a significant difference within 
the two age groups. I developed a specific procedure for how I selected my participants. First, the high school students and teachers were selected through a random cluster method. This method involved a drawing of three classes out of a pool of all of the United States History classes offered in the high school, including non-honors, honors, and advanced placement levels. The college professors and students were also selected the same way, with three classes selected randomly out of a pool of all U.S. History classes offered at the college. After determining this, I sent out emails to the corresponding teachers of the chosen classes. For the high school classes, two out of the three teachers were willing to participate right away. For the college professors, I had to randomly redraw additional rounds of classes multiple times and even draw classes from other colleges located in democratic counties in the state before I eventually found one professor who was willing to participate in my research. So, all in all, I was able to acquire two high school classes and one college class for participation in my research. After this, I went about sending out my consent forms detailing the procedures of my research, its pass of ethical standards, and the protection of participants. For the high school classes, I was able to print out hard copies of the forms and give them to the teachers to hand out to their students in their chosen class (there was an average of twenty five kids in each class). Since the high school students were all younger than 18 , they needed to have their consent forms signed by their parents in order to be eligible for participation. For the college professor, I sent a digital copy of my consent form via email for s/he to print and hand out to their students.

After this was completed, I gathered all of the completed consent forms from my participants. I collected the consent forms from the high school teachers and their students myself, while the college professor mailed the forms to my home address. Due to the fact that some students denied participation, I had gathered twenty high school student participants and twenty-one college student participants, as well as the two high school teachers and one college professor. Then, I began to gather my data. The instruments I used were surveys including Likert scale and interview questions that I developed on my own and were given to both student and teacher participants. The surveys, like the consent forms, were printed out and manually given to the high school classes and sent via email to the college professor to be printed out and completed. There were two types of surveys- one for the teachers to complete and one for the students to complete. The Likert scale questions in both surveys were used to measure the political perspective in which the participant leaned towards. The interview questions for the students' survey gained data about the students' own experiences with politics in the classroom and whether or not this impacted them personally. The interview questions for the teachers' survey measured their own view on whether or not politics should be used in the classroom setting as well as their own personal experiences on the topic. This method of acquiring data refers back to my mixed method that gathers both qualitative and quantitative data. My qualitative data contained information on both students and teachers and their experience with politics in the classroom. My quantitative data was through my use of the Likert scale that measured the political party that the students and teachers belonged to base on the number of statements they agreed with in regards to each party. Quantitative data also developed as I analyzed my qualitative data and created my own statistics and percentages. As with the consent forms, the completed surveys from the high school participants were collected directly by me and the surveys from the college participants were sent back to me from the professor via mail.

There are a number of limitations that exist within my method. First of all, there is a lack of validity that comes with the use of surveys, for participants may or may not be $100 \%$ truthful in their answers. Also, all of the participants were allowed to skip any questions they desire, which may have led to a lack of information that could skew my results. Furthermore, participants may not have been willing to open up about their own political experiences in the classroom, which could have also led to a lack of information for my study. 
Figure 1. Student Survey

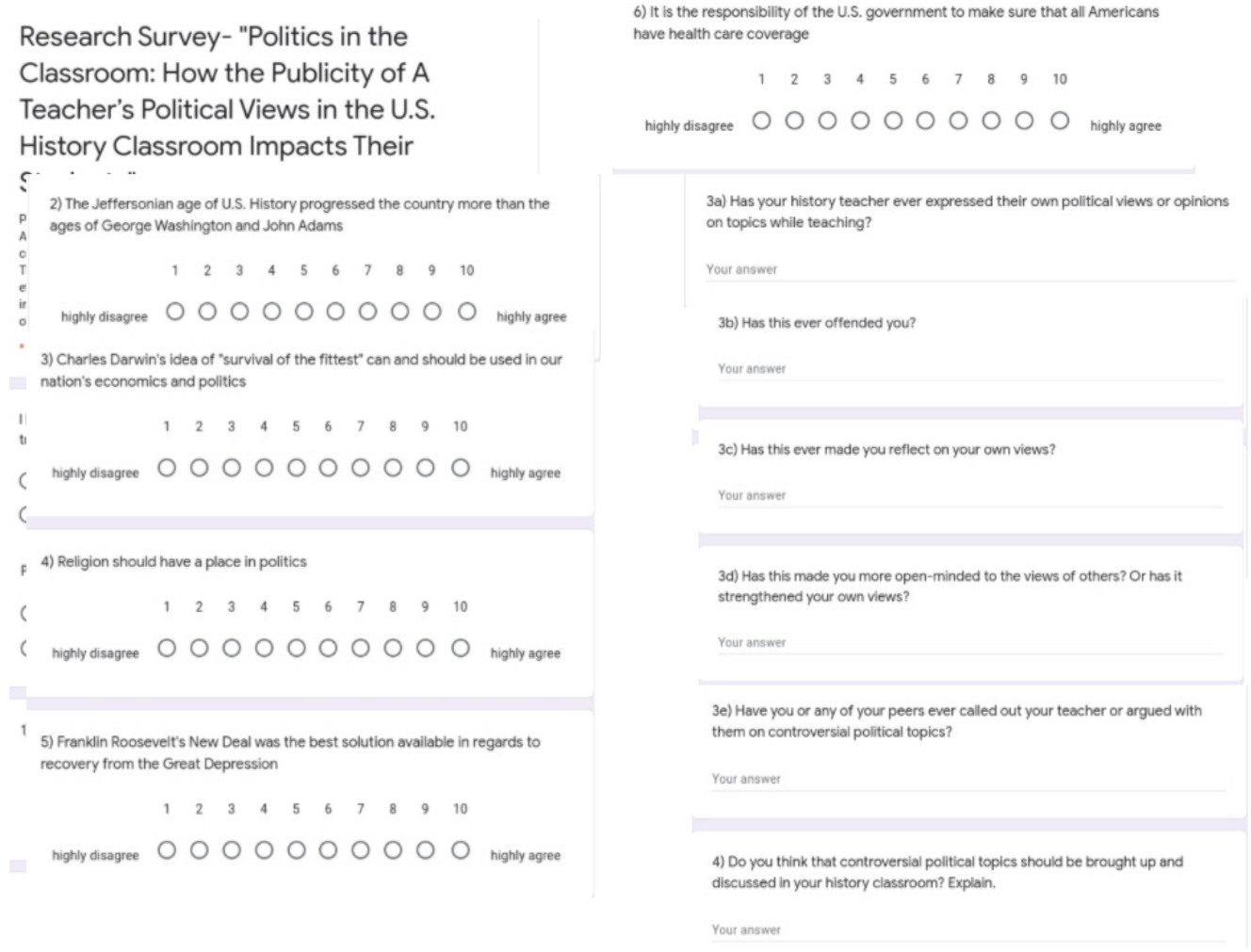

Figure 2. Question 1) Do you have a guess at what political views your current or a past history teacher holds based on things they have said in class? Once you made this assumption, did you perceive the way they taught the class material any differently?

High School Students

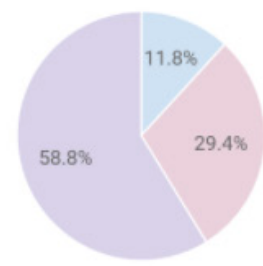

Has a guess at their view and percieve class differently

Has a guess at their view and doesn't

Doesn't have a guess at their view
College Students

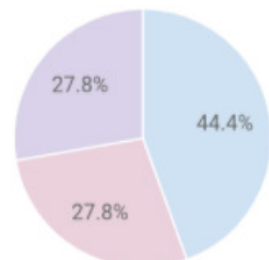

Has a guess at their view and percieve class differently

Has a guess at their view and doesn't percieve class differently

Doesn't have a guess at their view 
Figure 3. Question 2) Do you consider yourself to have strong political opinions?
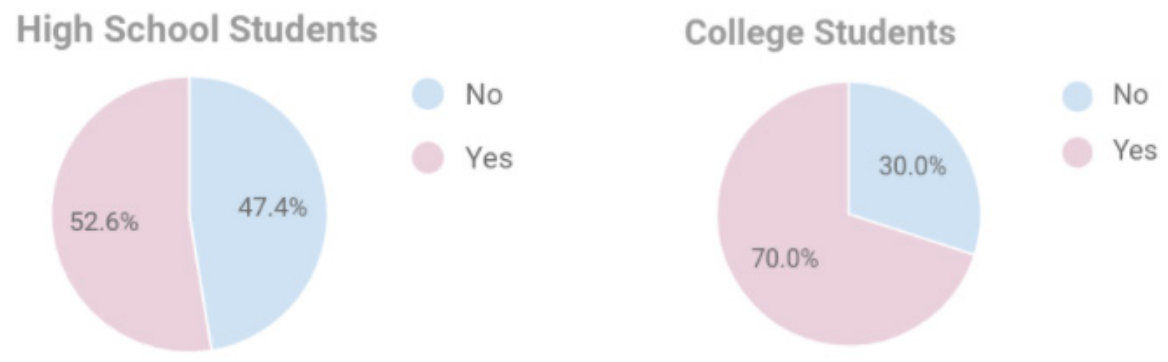

Figure 4. Question 3a) Has your history teacher ever expressed their own political views or opinions on topics while teaching?
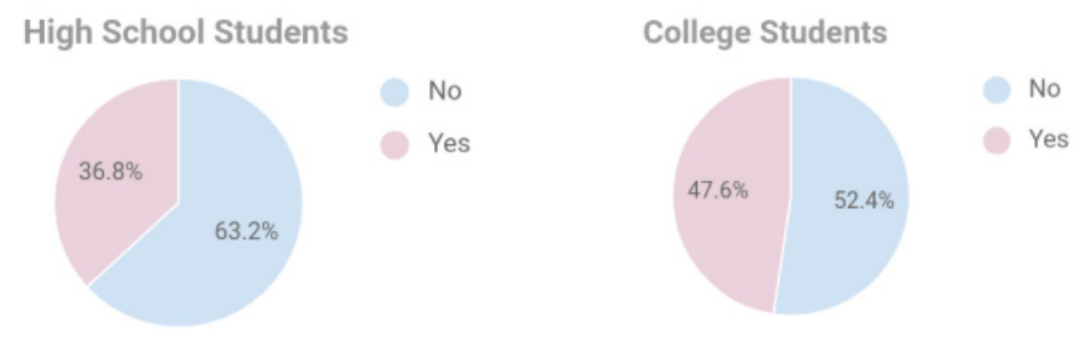

Figure 5. Question 3b) Has this ever offended you?
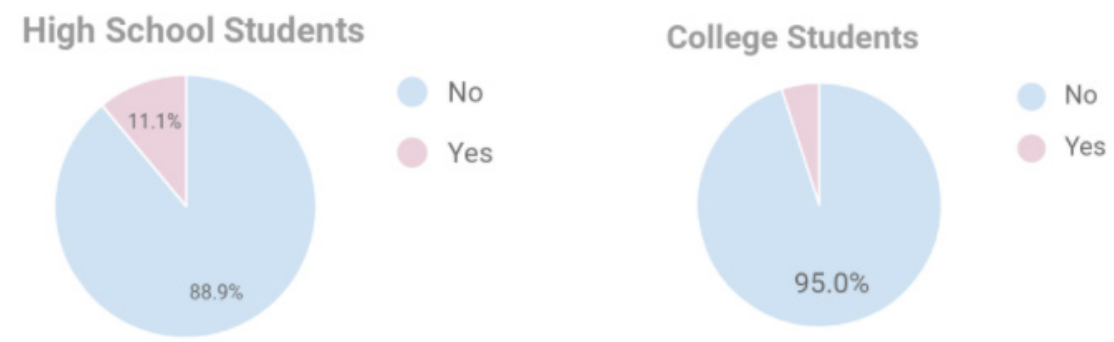

Figure 6. Question 3c) Has this ever made you reflect your own views?
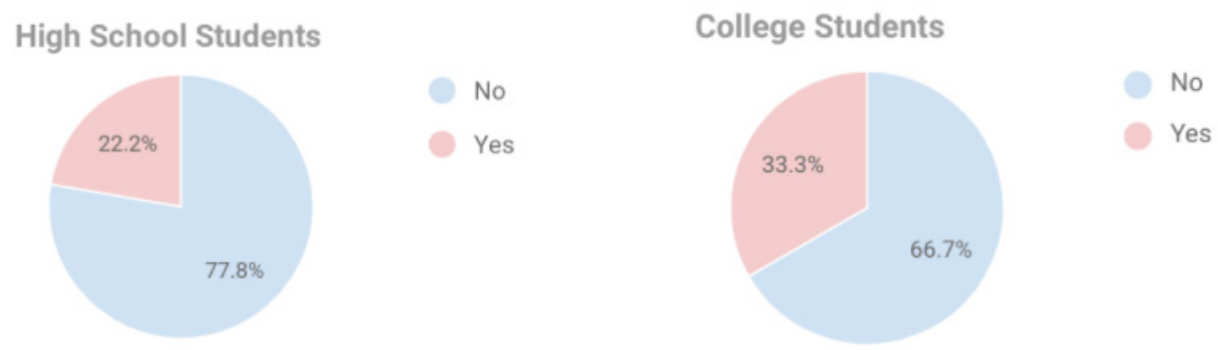
Figure 7. Question 3d) Has this made you more open-minded to the views of others? Or has it strengthened your own views?

High School Students

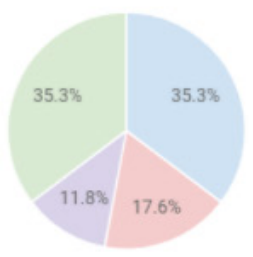

Both

More open-minded but views were not strengthened

Views were strengthened but not more open-minded

Neither
College Students

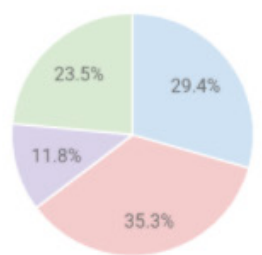

Both

More open-minded but views were not strengthened

Views were strengthened but not more open-minded

Neither

Figure 8. Question 3e) Have you or any of your peers ever called out your teacher or argued with them on controversial political topics?

High School Students

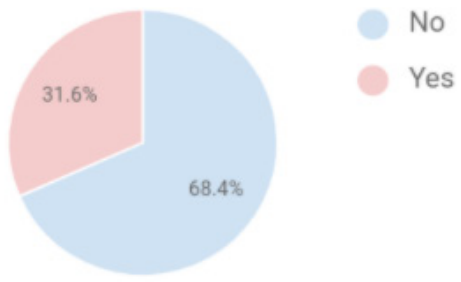

College Students

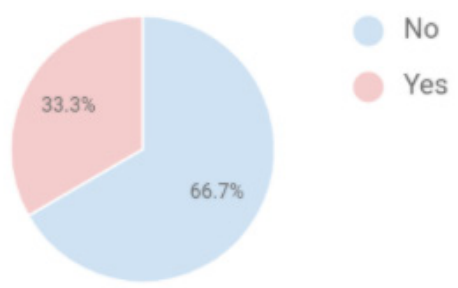

Figure 9. Question 4) Do you think that controversial political topics should be brought up and discussed in your history classroom?
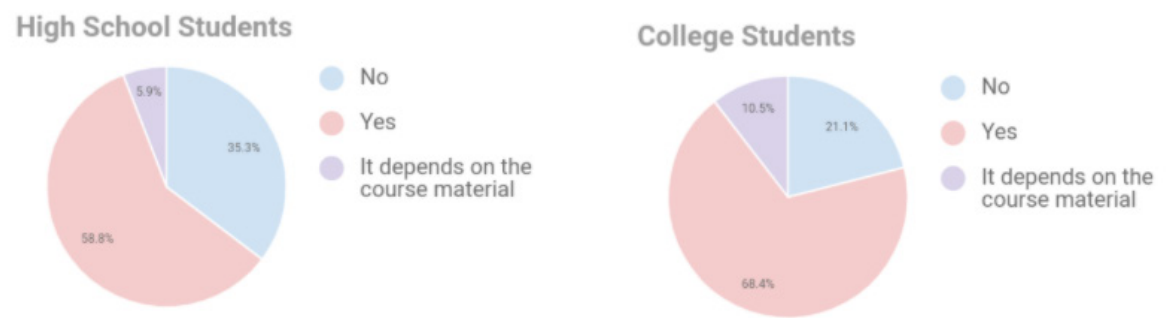
Figure 10. Teacher Survey

\section{Research Survey- "Politics in the Classroom: How the Publicity of A Teacher's Political Views in the Classroom Impacts Their Students"}

Flesse ansmer the folowina questions based on the degres in mhich you agree with them.

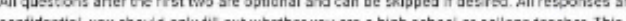

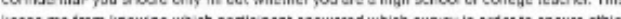

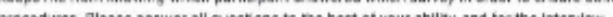

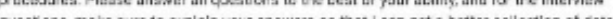

Thane you

+ Requinad

I heve read the conditions stated in the consent form and I give my ful consent to be a part of this study.

$\mathrm{O}$ yes

O No

Flease select the answer choice that described you *

O Iama high schood tascher

O lama college protessox

1) Taxos should be increasod for the weal thy in the United States

Nighiy disagree 0000000000 nighly agree

2) The Jefferscnian age of U.S. History progressed the country more than the ages of George Washington and John Adams

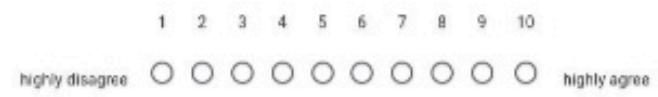

3) Charles Darwin's idea of 'survlval of the fittest can and shoudd be used in our nation's economics and politics

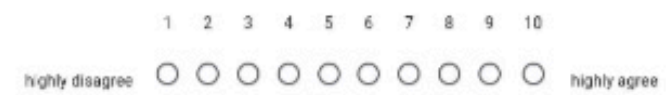

4) Religion should have a place in poiltics

$$
\begin{array}{llllllllllll} 
& 1 & 2 & 3 & 4 & 5 & 6 & 7 & 8 & 9 & 10 & \\
\text { hoghtg disagres } & 0 & 0 & 0 & \bigcirc & \bigcirc & \bigcirc & \bigcirc & 0 & 0 & 0 & \text { highly agree }
\end{array}
$$

5) Franklin Roosevelt's New Deal was the best solution wailable in regards to recovery from the Great Depression

$\begin{array}{llllllllllll} & 1 & 2 & 3 & 4 & 5 & 6 & 7 & 8 & 9 & 10 \\ \text { highty disagrese } & 0 & 0 & 0 & 0 & 0 & 0 & 0 & 0 & 0 & \text { highty agres }\end{array}$

\begin{abstract}
6) It is the responsibility of the U.S. government to make sure that all Americans hawe heal th care coverage

$\begin{array}{llllllllllll} & 1 & 2 & 3 & 4 & 5 & 6 & 7 & 8 & 9 & 10 & \\ \text { highly disagree } & 0 & 0 & 0 & 0 & 0 & \bigcirc & 0 & 0 & \bigcirc & 0 & \text { highly agree }\end{array}$
\end{abstract}

7) Having an increasing number of different races and ethnicity living in the U.S. reflects the meaning of the country

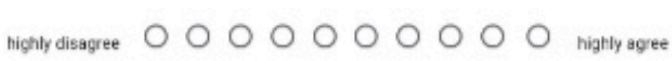

8) The U.S. occnomic system has always favored the wealthy

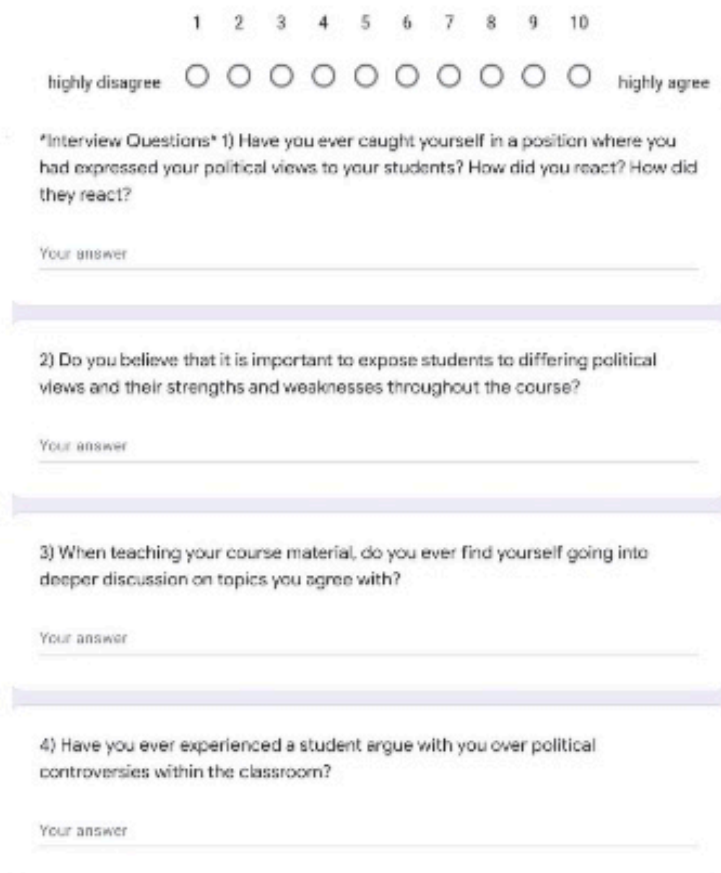

5) Shauld you have the right to express your political views while teaching?

Your answer 
Figure 11. Question 1) Have you ever caught yourself in a position where you had expressed your political views to your students?

High School Teachers

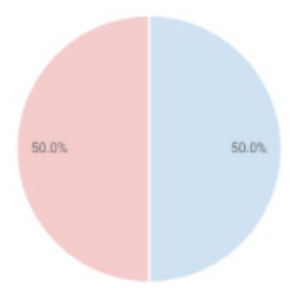

College Professor

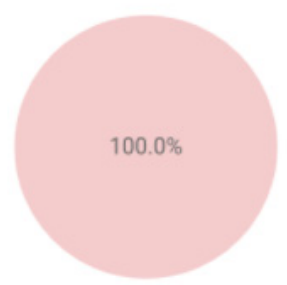

Figure 12. Question 2) Do you believe that it is important to expose students to differing political views and their strengths and weaknesses throughout the course?

High School Teachers

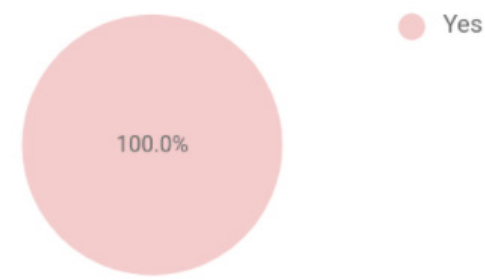

College Professor

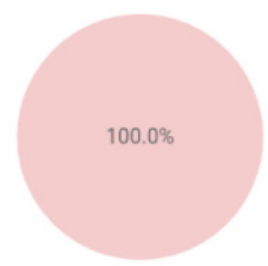

(1) Yes

Figure 13. Question 3) When teaching your course material, do you ever find yourself going into deeper discussion on topics you agree with?

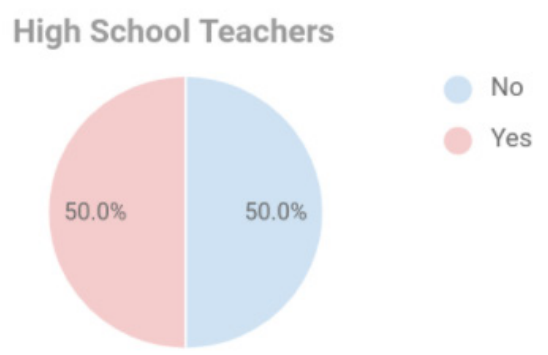

College Professor

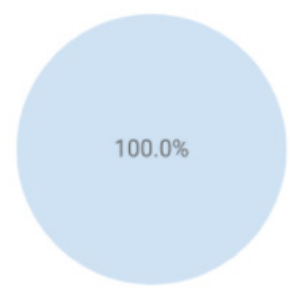

No

Figure 14. Question 4) Have you ever experienced a student argue with you over political controversies within the classroom?

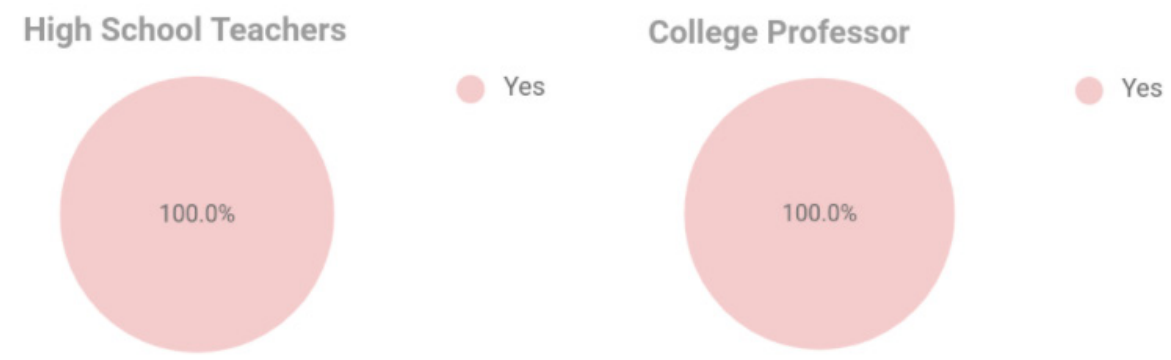


Figure 15. Question 5) Should you have the right to express your political views while teaching?

High School Teachers

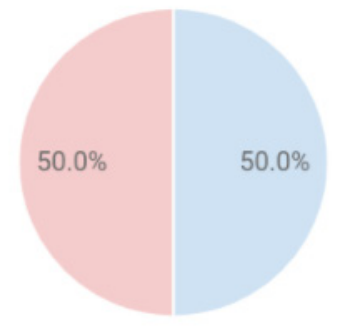

College Professor

No

Yes

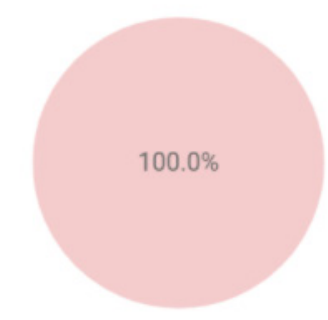

Yes

\section{Results}

The first step of the inquiry process was the gathering of completed surveys (Figures 1 and 2). The student survey (Figure 1) was given to a total of twenty high school students from two separate classes as well as twenty one college students from one class. The two high school teachers and the college professor were also given a survey to complete (Figure 2). However, the first eight questions -the questions with a Likert scale format- on both surveys were not taken into account in my results nor analysis. I had planned to use these questions to determine the political leanings of each participant in order to see if this influenced their answers, but I realized that this information is not relevant to my topic because I could not find any significant connection or pattern between the party affiliation of students and the way in which they answered each interview question. Furthermore, a number of students in their surveys stated that they did not associate themselves with a certain party or were even interested in politics at all. Therefore, I decided that it was not in my best interest to analyze my results based on how I measured each participant's political leanings. Instead, I decided to focus solely on the results from the interview questions in the survey. From the student surveys, approximately $57 \%$ of all students had a guess at their teacher's political affiliation (Figure 3) and $43 \%$ stated that their teacher had expressed their political opinions during instruction (Figure 5). Within this political publicity, 8\% felt offended (Figure 6), 28\% reflected their own views (Figure 7), and an overwhelming $71 \%$ felt more open minded and/or felt that their own views were strengthened (Figure 8). Furthermore, $72 \%$ of the students stated that political controversies and topics should be brought up and discussed in their classroom (Figure 10). For the teachers, 67\% have found themselves in a position where they shared their political views during discussion (Figure 11), 33\% found themselves going into deeper discussion on topics they agreed with (Figure 13), 100\% believed that controversial political topics should be discussed in their class (Figure 12), and 67\% believed that this includes their right to express their own political views during instruction (Figure 15). Overall, the majority of students and teachers recognized the prevalence of political publicity within their classroom.

\section{Analysis and Discussion}

With this data, I was able to measure the impact that a teacher's publicity of their political views during instruction has on their students. I found that this exposure does in fact contribute to the development of the political views of the students. This development of the students' views over the course of their U.S. History class comes from the strengthening of their previous views that stems from self-reflection. When the students hear the opinions of their instructors on political topics they are learning about, they tend to compare these opinions to their own views. I have found that whether the student disagrees or agrees with the political statement of their teacher, the majority find their own views strengthened after reflection. One college student states, "when I hear opinions that differ from mine, I'm open minded and respectful but inwardly I think my views are strengthened." Another who has heard and agreed with their 
professor's opinions during instruction states that their views are also "strengthened because I know what's right for my views". These responses both reflect the statistical data I gathered in Figure 3 in regards to the strengthening of the student's political views upon hearing those of their instructor. This, in turn, leads to a continued development of their previous views that they have created and held from past experiences. The teachers' contribution to the evolution of their students' political views can also be proven by the way in which their political views shape their method of teaching the course material, and therefore, the way in which the students perceive it. A large percent of the students surveyed stated that they had recognized their teacher's publicity of their political views in the classroom, and while a majority believed this didn't change the way they learned the material, a significant part of the sample did. When asked if they knew their teacher's political stance and believed that this affected their teaching, one college student replied, "yes, I did view their opinions differently," another stated, "yes, yes absolutely," another answered, "yes, because the information became biased on one's belief," and a high school student stated, "not my current teacher but ones I have had in the past- I did perceive material differently". These responses show that when a teacher inputs their own opinion during class instruction, it can in fact have an impact on the way their students learn about the history of their nation and can ultimately influence the way they see both historical and current real-world political issues. This impact of the teachers' political publicity can also be proven by the teachers who admitted to spending more time and diving deeper into discussion on topics they agreed with. This additional discussion expands the level to which the students are exposed to their teacher's opinions and shapes the way in which they learn about U.S. history. While this political exposure on the surface seems irrational and untamed, the majority of both students and professors alike believe that it is necessary to provide an educated, civic public. A number of students share opinions along the lines of "it is important to discuss what is happening in the world, and students need to understand why its controversial", "it helps encourage different opinions", "we as a nation should be able to have informed conversations on the topics/issues in our country", and "politics play a huge role in history and how history is viewed". Furthermore, teachers expand on these opinions with responses such as "students should be able to hear different perspectives and the logic behind those perspectives. This will allow students to make their own assessment of a topic" and "I encourage teachers to look at varying new sites, look at both sides, talk to different people - I don't think anyone should be too narrowly focused because it would be a disservice to the student". Another interesting facet of my research was that the percentages of college students who felt both the change in the development and growth of their existing political views from both past and current U.S. history professors is greater than the percentages of these effects felt by high school students: $10.8 \%$ more college students acknowledged the presence of their teacher's political views during instruction, $11.1 \%$ more saw themselves reflecting their own views after this publicity, $11.8 \%$ more felt their views either strengthened, more open-minded, or both. This gives the idea that college professors might express their political views more openly and freely than high school teachers. Or, this finding can mean that college students might be more educated and aware of political topics and opinions due to higher maturity levels and more experience than high school students, which may make it easier for them to identify the publicity of their professor's views and see how it affects them. This second idea can also be explained by the greater percent of high school students (10.6\%) who felt offended after hearing their teachers speak about their personal political views. Despite the differences in college and high school responses, it can be seen within my data that teacher political publicity does have an impact on the American student body as a whole, and the majority of both students and teachers agree that this exposure is important. Ultimately, these discussions are needed in order to educate students on real-world issues. Whether it is beneficial or detrimental, the publicity of their instructor's political opinions within the classroom during these conversations and teachings allow the students at both the college and high school level to develop and expand on their own views.

\section{Limitations}

With my research process, there were a number of limitations that I came across. One of the most prevalent was that I had only gathered twenty high school students and twenty-one college students to participate. I aimed to gather at least thirty participants for each group, but unfortunately the process of signing consent forms and taking the time to 
complete my survey deemed too inconvenient for a number of students. Another limitation was that I was only able to gather data from one college professor, rather than my goal of two or three. Around forty different college professors from a number of colleges in democratic counties in the state were emailed and invited to participate in my study. The majority did not respond back, and a number of others agreed to participate in the beginning but then backed out of the study after reviewing the content of my surveys. One professor even wrote me a lengthy email that explained his fear in participating in my research due to his claim that I cannot control where my findings end up, and if it gets in the wrong hands it can have consequences on his reputation that has already been targeted for his expression of his political beliefs. Furthermore, some professors did not respond until weeks later, which proved to be inevitably impossible to gather my data within the allotted time frame. On the other hand, the first two high school teachers I emailed responded immediately and data from them and the students was collected within a week. While there was a lack of a plural number of college professors to study, my difficulty in gathering professor participants from their desire of their own protection suggests the idea that they value and use their political views while teaching more so than the high school teachers, possibly strengthening my claim that college students feel a greater impact from teachers' political publicity than high school students. Another limitation was the inability to ensure the validity and honesty of participants' answers to my surveys. Furthermore, the fact that respondents had the option to skip questions they did not want to answer may have skewed or affected my data in ways that I cannot measure.

\section{Conclusion}

Despite these limitations, after evaluating the impacts of teachers' political publicity in an educational classroom at both the high school and college level, I have found that this exposure strengthens the existing views of most students and also changes the students' perception of the course material taught. These findings lead to my conclusion that this political publicity does, in fact, impact and develop students' own political views at both the high school and college level. Furthermore, my data also uncovered the finding that this impact is greater at the college level, supporting my initial hypothesis. My quantitative data -statistics and percentages of the student and teacher responses to the surveypaired with my qualitative data -thorough descriptions to interview questions provided by the respondents- provide for a mixed method of results that brought me to my conclusion. The percentages show the great number of students who felt affected by their exposure to their teacher's political views, both negative and positive, and the descriptions provide further evidence of individual cases and opinions on the topic that support my claim. Furthermore, my data in regards to the percentages of college students who felt both the change in the development and growth of their existing political views from both past and current U.S. history professors is greater than the percentages of these effects felt by high school students, supporting the existing idea that college professors have more political freedom than high school teachers. This finding can also imply that college students may be more educated and aware of political topics and opinions due to higher maturity levels and more experience than high school students, which may also make it easier for them to identify the publicity of their professor's views and see how it affects them. Overall, my findings add a new discovery towards the role of teachers in how the American civic society is developed. These discoveries open the door for new research on the difference in both societal and moral restrictions on the publicity of political views between college professors and high school teachers as well as research on the impact of maturity and age on the awareness of one's political views and their recognition of others'. Based on my findings, I believe that action should be taken to determine if the political publicity of teachers is beneficial or detrimental to not only students, but society as a whole, and based on this, whether or not teachers should be given the legal right to express their views during instruction. 


\section{Bibliography}

Ideologies of political parties in the United States. (n.d.). Retrieved December 1, 2019, from https:/www.khanacademy.org/humanities/us-government-and-civics/us-gov-american-political-beliefs-and-behaviors/us-gov-ideologies-of-political-parties/v/ideologies-of-political-parties-in-the-united-states.

Joumell, W. (2014). Teaching Politics in the U.S. History Classroom. History Teacher, 48(1), 55-69. Retrieved from http://search.ebscohost.com/login.aspx?direct=true \&db=aph\&AN=99803672

South Carolina Election Results 2016. (2017, August 1). Retrieved December 1, 2019, from https://www.nytimes.com/elections/2016/results/south-carolina.

Talamante, L. E. (2008). Teaching U.S. History with an Eye to the World. History Teacher, 41(3), 391-404. Retrieved from http://search.ebscohost.com/login.aspx?direct=true \&db=asn\&AN=32672038\&site=ehostlive

Waalkes, S. (2003). Using Film Clips as Cases to Teach the Rise and "Decline" of the State. International Studies Perspectives, 4(2), 156-174. Retrieved from https://doi.org/10.1111/1528-3577.402004

Wegwert, J. C. (2014). Looking the tiger in the eye: overcoming fear-based teacher identities. Childhood Education, 90(2), 137+. Retrieved from https://link.gale.com/apps/doc/A365687314/GPS?u=moun19932\&sid=GPS\&xid=8c0dadb 